\title{
Effect of Climate Change on Agricultural Technologies and Determinants of Adaptation Strategies by Small-holder Farmers in Benishangul-Gumuz Regional State of Ethiopia
}

\author{
Regasa Dibaba ${ }^{1}$, Afework Hagos ${ }^{1}$, Adam Bekele ${ }^{2}$
}

\author{
${ }^{1}$ Ethiopian Institute of Agricultural Research, Assosa Agricultural Research Center, Assosa, Ethiopia \\ ${ }^{2}$ Ethiopian Institute of Agricultural Research, Melkasa Agricultural Research Center, Adama, Ethiopia \\ regasadibaba.com
}

\begin{abstract}
Adaptation to climate change involves changes in agricultural technologies in particular and management practices in general to reduce its risk and effects. To minimize the effects due to climate change factors, the farmers have employed different climate change adaptation strategies. Consequently, this study examines small-holder farmers' adaptation strategies to climate change in Benishangul-Gumuz Regional State of Ethiopia based on a cross-section data collected from Assosa, and Kamashi zones and Mao-Komo special district. The study describes the perceptions of smallholder farmers to climate change indicators and adaptation measures at the farm household level using multivariate discrete choice model to identify the determinants of adaptation strategies. The econometric model has revealed that households demographic factors, resources endowments (land, labour, livestock), institutional factors (access to extension services, cooperative membership and access to credit) were some of the important determinants of farm-level adaptation strategies. The policy implication from our finding is that improving access to credit, better use of production factors (like land, labor) and enhancing the bargaining power of smallholder farmers can significantly increase farm-level adaptation to climate change. Furthermore, adopting different improved crop varieties have showed better yield gains than non-adopters. Thus, policies and strategies should focus at research and development on appropriate technologies that help smallholder farmers' adaptation capacity to climate changes hereby varietal development, appropriate agronomic recommendations, pre-extension demonstration and popularization of improved cultivars and promoting appropriate farm-level adaptation measures such as use of irrigation technologies.
\end{abstract}

Keywords: Climate change, adaptation strategy, microlevel, crop technology

\section{INTRODUCTION}

Climate change is currently threatening the livelihoods of millions of people who are already poor and vulnerable, by altering the natural and physical assets they rely on, particularly for agricultural production. Climate change is expected to present heightened risk, new combinations of risks and potentially grave consequences on daily life and economic activity.

Available evidence shows that climate change is global, likewise its impacts; but the most adverse effects will be felt mainly by developing countries, especially those in Africa, due to their low level of coping capabilities (Nwafor 2007; Jagtap 2007). Adaptation to new climatic conditions is, hence, a necessary strategy for those living in the affected parts of the world. Adaptation comprises measures of prevention as well as measures of adopting a change in a traditional way of life.

Climate change adaptation aims to mitigate and develop appropriate coping measures to address the negative impacts of climate change on agriculture. Most agricultural system shave a measure of in-built adaptation capacity ("autonomous adaptation") but the current rapid rate of climate change will impose new and potentially 
Effect of Climate Change on Agricultural Technologies and Determinants of Adaptation Strategies by Small-holder Farmers in Benishangul-Gumuz Regional State of Ethiopia

overwhelming pressures on existing adaptation capacity. This is particularly true given that the secondary changes induced by climate change are expected to undermine the ability of people and ecosystems to cope with, and recover from, extreme climate events and other natural hazards. Accordingly, there is a growing focus on the need for "anticipatory adaptation" (UNDP, 2007), that is the proactive rather than the reactive management of climate change risk. Anticipatory adaptation relies on the best available information concerning the nature of future climate risks.

In order to adapt to climate change, farmers will need access to new and improved technologies, skills and knowledge. The most appropriate technologies can enable the farming community to improve their livelihoods even when there is uncertainty about the future climate. Many such technologies are already in use at the local level. The impact of climate change and the role of technologies as adaptation strategies are of concern to Ethiopia's agriculture where the majority of the farmers are smallholders with limited option to fight against climatic change consequences; i.e. low level of agricultural production with corresponding negative effects on food security.

The Ethiopian Institute of Agricultural Research in collaboration with stakeholders in agricultural research and development has been contributing to the development of agriculture in the country through generating, development, transfer and facilitating the adoption of agricultural technologies. To this effect a number of crop, livestock and natural resource related technologies have been disseminated among smallholder farmers who face and confront the vagaries of the ever-changing climate. New technologies and practices that are resistant to drought are developed to reduce the risk of famine and increase returns.

However, very little is known about the roles of these technologies in fighting against climate change and the associated impact on farmers' choice of adaptation strategies. The climate change technology needs assessment study also makes provision for the need to assess the technological options in the context of climate change (NMA, 2007). There is a need to target appropriate policy recommendations on technology transfer to facilitate climate change adaptation and mitigation as effective ways of promoting agricultural development. Also there is need for effective policy responses to encourage the development, transfer and diffusion of appropriate agricultural technologies to promote food security, agricultural development and climate change adaptation and mitigation in the face of changing climatic scenario.

In this study the process of adaptation to climate change via choice of technology will be studied. Hence, the overall objective of this study is to assess farmers' perception on climate change indicators and crop technologies as climate change adaptation strategies and identify determinants of use of crop technologies as climate change adaptation strategies by farm households in the study area.

\section{Material AND Methods}

\section{Dataset and Variables}

\section{Sampling and Data Collection}

The research was conducted at crop livestock mixed farming system in Benishangul Gumuz Region of Ethiopia. The survey was conducted at Mao-Komo special district, Assosa and Kamashi Zones of Benishangul Gumuz region. The study areas were classified based on climatic variability. The common classifications, Dega, Weinadega and Kolla were used to define the study areas. Two zones and one special district with three villages per district were identified. This study considers households as unit of analysis for decision making. A total of 204sample households were randomly identified from selected districts based on proportion to size criteria (see table 1). About $81 \%$ and $19 \%$ of the sampled households farming type was crop-livestock mixed farming and crop only respectively.

American Research Journal of Business and Management Page 2 
Effect of Climate Change on Agricultural Technologies and Determinants of Adaptation Strategies by Small-holder Farmers in Benishangul-Gumuz Regional State of Ethiopia

Sampled household heads were interviewed using a well-defined interview schedule. The type of data collected pertains household characteristics (demography, asset ownerships, farming experience, education and physical/ natural resources), livelihood strategies (income generation and adaptation mechanisms), technological options, farming/institutional environment (access to support institutions: finance, input, market, technical backstopping,), the biological environment (drought, pests),

Table1. Total sampled households

\begin{tabular}{|c|c|c|c|}
\hline District & Total no of households & nTotal & $\sim \mathbf{n}$ \\
\hline Mao-Komo & 8,554 & 70.25 & 70 \\
\hline Bambasi & 12,539 & 102.98 & 103 \\
\hline Kamashi & 3,552 & 29.17 & 31 \\
\hline Total & 24,645 & 202.41 & $\mathbf{2 0 4}$ \\
\hline
\end{tabular}

\section{Data Analysis and Model Specification}

\section{Determinants of Participation and Interaction: Multivariate Probit Model}

Data were analyzed using descriptive, exploratory and econometric techniques. The descriptive approach includes percentages, mean, median standard deviation and appropriate statistical tests. It involves tabular analyses and testing the distributional importance of agricultural technologies and climate change adaptation mechanisms.

However, the above univariate probit and multinomial probit estimationsof climate change adaptations strategymeasures would be misleading for the expected problem of simultaneity. Theadoption of one type of agricultural technology would be dependent on the adoption of the other,since household adoption decisions are interdependent, suggesting the need to estimate themsimultaneously. To account for this, a seemingly unrelated multivariate probit simulationmodel was employed (Long 1997; Chib\& Greenberg 1998; Cappellari\& Jenkins 2003, Degieet al., 2013):

$$
\begin{gathered}
\text { Cropdiv }_{i}{ }_{i}=X_{1}{ }^{\prime} \beta_{1}{ }^{*}+\varepsilon_{1 i}, \\
\operatorname{Irr}_{i}^{*}=X_{2}{ }^{\prime} \beta_{2}{ }^{*}+\varepsilon_{2 i}, \\
\text { DiffVar }{ }_{i}=X_{3}{ }^{\prime} \beta_{3}{ }^{*}+\varepsilon_{1 i}, \\
\text { LandChange }{ }_{i}=X_{4}{ }^{\prime} \beta_{4}{ }^{*}+\varepsilon_{4 i}, \\
\text { CapitallabChange }{ }_{i}=X_{5}{ }^{\prime} \beta_{5}{ }^{*}+\varepsilon_{5 i}, \\
\text { ChemicalSpraying }{ }_{i}=X_{6}{ }^{\prime} \beta_{6}{ }^{*}+\varepsilon_{6 i}, \\
\text { Ridge }_{i}=X_{7}{ }^{\prime} \beta_{7}+\varepsilon_{7 i},
\end{gathered}
$$

DiffPlDat ${ }_{i}=X_{8}{ }^{\prime} \beta_{8}{ }^{*}+\varepsilon_{8 i}$,

Where;

$$
\begin{aligned}
& {\left[\begin{array}{l}
\varepsilon_{1 i} \\
\varepsilon_{2 i} \\
\varepsilon_{3 i} \\
\varepsilon_{4 i} \\
\varepsilon_{5 i} \\
\varepsilon_{6 i} \\
\varepsilon_{7 i} \\
\varepsilon_{8 i}
\end{array}\right]=\sim N\left[\begin{array}{l}
0 \\
0 \\
0 \\
0 \\
0 \\
0 \\
0 \\
0 \\
0 \\
0
\end{array}\right]\left(\begin{array}{cccccccc}
1 & \rho_{12} & \rho_{13} & \rho_{14} & \rho_{15} & \rho_{16} & \rho_{17} & \rho_{18} \\
\rho_{21} & 1 & \rho_{23} & \rho_{24} & \rho_{25} & \rho_{26} & \rho_{27} & \rho_{28} \\
\rho_{31} & \rho_{32} & 1 & \rho_{34} & \rho_{35} & \rho_{36} & \rho_{37} & \rho_{38} \\
\rho_{41} & \rho_{42} & \rho_{43} & 1 & \rho_{45} & \rho_{46} & \rho_{47} & \rho_{48} \\
\rho_{51} & \rho_{52} & \rho_{53} & \rho_{54} & 1 & \rho_{56} & \rho_{57} & \rho_{58} \\
\rho_{61} & \rho_{62} & \rho_{63} & \rho_{64} & \rho_{65} & 1 & \rho_{67} & \rho_{68} \\
\rho_{71} & \rho_{72} & \rho_{73} & \rho_{74} & \rho_{75} & \rho_{76} & 1 & \rho_{78} \\
\rho_{81} & \rho_{82} & \rho_{83} & \rho_{84} & \rho_{85} & \rho_{86} & \rho_{87} & 1
\end{array}\right)} \\
& E(\varepsilon \mid X)=0 \\
& \operatorname{Var}(\varepsilon \mid X)=1 \\
& \operatorname{Cov}(\varepsilon \mid X)=\rho
\end{aligned}
$$


Effect of Climate Change on Agricultural Technologies and Determinants of Adaptation Strategies by Small-holder Farmers in Benishangul-Gumuz Regional State of Ethiopia

Where $\operatorname{Cropdiv}_{i}{ }_{i}, \operatorname{Irr}_{i}{ }_{i}$, DiffVar $_{i}{ }_{i}$, LandChange $_{i}{ }_{i}$, CapitallabChange $_{i}{ }_{i}$, ChemicalSpraying $_{i}$, $R_{i a g e^{*}}{ }_{i}$ and $D i f f P l D a t^{*}{ }_{i}$ are households' climate change adaptation strategies like crop diversification, use of irrigation, adoption of different crop improved varieties, land change, capital and labor change, use of chemical spraying, using soil and water conservation techniques like ridging and changing planting date based on the offsetting of the rainfall respectively. $x_{1} t_{0} x_{8}$ are vectors of independent variables determining the respective climate change adaptation strategies; $\beta^{\prime} s$ are vectors of simulated maximum likelihood (SML) parameters to be estimated; $\varepsilon_{1 i}$, to $\varepsilon_{8 i}$, are correlated disturbances in a seemingly unrelated multivariate probit model; and $\rho^{\prime}$ s are tetra choric correlations between endogenous variables. In our case there are 58 joint probabilities corresponding to the eight possible combinations of successes (with value of 1 ) and failures (with value of 0 ). For instance, if we take the probability that every outcome is a success, the probabilities that the likelihood function of the climate change adaptation strategies simulation are explained as

$\operatorname{Pr}($ Cropdivi $=1$, Irr $i=1 ;$ DiffVari $=1$;

LandChange ${ }_{i}^{*}=1$; CapitallabChange ${ }_{i}=1$;

ChemicalSprayingi $=1$, Ridge $i=1$, DiffPlDat $i=1$

$=\Phi_{m}\left(X_{1} \beta_{1},{ }^{\prime} X_{2} \beta_{2}{ }^{\prime}, X_{3} \beta_{3}{ }^{\prime}, X_{4} \beta_{4}{ }^{\prime}, X_{5} \beta_{5}{ }^{\prime}, X_{6} \beta_{6}{ }^{\prime}, X_{7} \beta_{7}{ }^{\prime}, X_{8} \beta_{8}{ }^{\prime}, \rho\right)$

$=\operatorname{Pr}\left(\varepsilon_{1 i} \leq X_{1} \beta_{1}{ }^{\prime} \varepsilon_{2 i} \leq X_{2} \beta_{2}{ }^{\prime}{ }^{\prime} \varepsilon_{3 i} \leq X_{3} \beta_{3}{ }^{\prime}, \varepsilon_{4 i} \leq X_{4} \beta_{4}{ }^{\prime}, \varepsilon_{5 i} \leq X_{5} \beta_{5}{ }^{\prime}, \varepsilon_{6 i} \leq X_{6} \beta_{6}{ }^{\prime}, \varepsilon_{7 i} \leq X_{7} \beta_{7}{ }^{\prime}, \varepsilon_{8 i} \leq X_{8} \beta_{8}{ }^{\prime}\right.$

Where, $\Phi_{m}$ is multivariate standard normal distribution

To estimate the interdependence of household decision to adopt climate change adaptation strategies, the above equation was used with eight endogenous variables.

\section{Variables definition and hypothesis}

\section{Dependent variable for Multivariate probit model}

The choice of adaptation strategies from the set of adaptation options in multivariate probit model are assumed to be done among the most prevalent adaptation mechanism in the study area. Changing planting dates, changing crop varieties, changing crop types, using irrigation, soil and water conservation practices are some of these adaptation mechanisms and options for climate change in rain-fed agriculture of many African countries (Nhemachena and Hassan, 2007). The adaptation choices for this study are based on the asking sample households the actions taken to counterbalance the negative effect of climate change.

\section{Independent Variables for Multivariate Probit Model}

The explanatory variables for this study are those factors which are expected to affect smallholder farmers' choices of adaptation strategies against climate variability.

Dependency ratio is a continuous variable ranging between zero and one, which refers to the number of family members which are dependent.

Land holding is a continuous variable measured in hectares. Hassan and Nhemachena (2008) reported that larger farm size was found to encourage the use of multiple cropping and integration of a livestock component, especially under dry land conditions. Large land holdings allow farmers to diversify their crop and livestock options and help spread the risks of loss associated with changes in climate. Since land holding is associated with greater wealth, the study hypothesized land holding has positive relation crop diversification with adaptation option to the climate change.

American Research Journal of Business and Management Page 4 
Effect of Climate Change on Agricultural Technologies and Determinants of Adaptation Strategies by Small-holder Farmers in Benishangul-Gumuz Regional State of Ethiopia

Credit: it is a dummy variable that takes a value of 1 if received credit and 0 otherwise. Availability of credit eases the cash constraints of households and allows purchasing inputs like fertilizer, improved crop varieties, irrigation facilities and so on. Credit access and use has a positive impact on climate change and variability adaptation strategies (Aemiroet al., 2012).

Location: is dummy variable that takes a value of 1 and 0 otherwise. Farmers living in different agro ecological zones make use of different adaptation strategies (Temesgenet al., 2009; Aemeroet al., 2012,).

Frequency of contact with Extension agents: It is a discrete variable measured by the number of contacts made with extension workers in the year. It creates access to information and technical assistance on agricultural activities and adaptation methods through extension services. Access to extension services has a positive impact on the probability of adopting adaptation strategies to climate change and variability (Aemroet al., 2012; Belainehet al., 2013).

Distance to market: is a continuous variable and measured in kilometers from home of the households to the nearest market. The closer the farmer is to the market the more likely the farmer receives valuable information and purchase agricultural inputs. Proximity to market is an important determinant of adaptation. A long distance to markets decreases the probability of farm adaptation in Africa due to market provides an important platform for farmers to gather and share information (Maddison, 2006).

Experience in using fertilizer and post-harvest technologies have also an impact on climate variability adaptation strategies.

Frequency of extension contacts: This is a continuous variable which takes avisiting time by extension agent per year. Extension on crop and livestock production and information on climate represent access to the information required to make the decision toadapt to climate change.

Table2. Variables used in the multivariate probit model and expected signs

\begin{tabular}{|l|l|l|l|}
\hline Name of Variable & Type of variable & Unit of Measurement & Expected Sign \\
\hline Dependence ratio & Continuous & Ratio & - \\
\hline Total Land owned & Continuous & Ha & $+/-$ \\
\hline Cooperative membership & Dummy & yes=1,0=No & + \\
\hline Credit access & Dummy & yes=1,0=No & + \\
\hline Family size & Continuous & No. of persons & $+/-$ \\
\hline District & Dummy & yes=1,0=No & $+/-$ \\
\hline No. of Extension Visit & Continuous & Number & $+/-$ \\
\hline Distance to Extension office & Continuous & Ha & + \\
\hline Distance to grain market & Continuous & Hectares & + \\
\hline Mixed crop-livestock farming system & Dummy & yes=1,0=No & $+/-$ \\
\hline Fertilizer use experience & Continuous & Years & $+/-$ \\
\hline Post-harvest technologies use experience & Continuous & Years & $+/-$ \\
\hline
\end{tabular}

\section{RESULT AND DISCUSSION}

\section{Socio-Economic Characteristics}

Based on proportional to size about 50\% of the sampled households were from humid intermediate, 35\% (crop livestock mixed farming system and highland and the remaining $15 \%$ were from humid lowland agro-ecology, respectively.Land ownership has an effect on technology adoption, enterprise choice and market orientation. Due to demographic, economic, institutional and environmental factors (climate change) it is clear that the demand for agricultural land is increasing at an alarmed rate. Cognizant to this fact, the government of Ethiopia has currently recognized the importance of land as a key strategic resource to drive smallholders out of poverty. 
Effect of Climate Change on Agricultural Technologies and Determinants of Adaptation Strategies by Small-holder Farmers in Benishangul-Gumuz Regional State of Ethiopia

Hence, land use and ownership pattern has an effect on impacts of climate change. The total share cropped and cultivated land showed slight increase. Thus, this indicates that farmers are searching alternative land use patterns to solve land shortage for agricultural production activities.

Furthermore, it is important to note that self-owned cultivated land showed greater variability due to the fact that the farmers have started cultivating fallow land due to the increase in their family size, decrease in fertility of their farm land and increase in crop diversification to minimize risk. In addition, about $14.15 \%$ and $6.83 \%$ of the households revealed that self-owned cultivated land is decreased by less than $50 \%$ and $>50 \%$ in the last ten years. This may be due to low soil fertility status and acidity problems of their farmland, the farmers have abandoned cultivating their land. This needs an urgent solution to reclaim their farm land through sustainable soil and water management techniques to enhance land production and productivity.

Table3. Land holding pattern of the households since the last 10 years

\begin{tabular}{|l|c|c|c|c|c|}
\hline \multicolumn{1}{|c|}{ Variable } & $\begin{array}{c}\text { Increase } \\
(>50 \%)\end{array}$ & $\begin{array}{c}\text { Increase } \\
\text { (up to 50\%) }\end{array}$ & Same & $\begin{array}{c}\text { Decrease } \\
(<50 \%)\end{array}$ & $\begin{array}{c}\text { Decrease } \\
(>50 \%)\end{array}$ \\
\hline Self-owned total land & 3.90 & 12.2 & 67.78 & 13.17 & 1.95 \\
\hline Self-owned cultivated land & 4.39 & 20.49 & 54.15 & 14.15 & 6.83 \\
\hline Rented in total land & 0.49 & 2.93 & 96.10 & 0.00 & 0.49 \\
\hline Rented in cultivated land & 0.98 & 1.95 & 96.58 & 0.00 & 0.49 \\
\hline Total share cropped land & 2.44 & 5.85 & 87.32 & 2.44 & 1.95 \\
\hline Sharecropped cultivated land & 1.95 & 6.34 & 85.37 & 3.41 & 2.93 \\
\hline
\end{tabular}

Source: survey results, 2016

\section{Farmers' Perception on Climatic Change}

In order to get essential information and insight into farmers' adaptation to climate change, looking at their perception on each parameter/indicators are quite important. Hence, knowledge about farmers' perception on climate change attributes in the study area is an appropriate issue to be discussed. For this purpose, different climate change attributes have been used. Parameters such as excessive hotness, erratic rainfall, environmental change, occurrence of disease were used to describe farmers' perception on climate change.

Table4. Effects of climate change and perception of households

\begin{tabular}{|c|c|c|}
\hline \multirow{2}{*}{ Indicators of climate change effects } & \multicolumn{2}{|c|}{ Frequency (percentage) } \\
\hline & Yes & No \\
\hline Leads to hotness of the body & $114(55.61)$ & 91(44.39) \\
\hline Health illness & $65(31.71)$ & $140(68.29)$ \\
\hline Changing the environment & $68(33.17)$ & $137(66.83)$ \\
\hline Excessive heating & $63(30.73)$ & $142(69.27)$ \\
\hline Reduces the rain-fall amount & $9(4.39)$ & $196(95.61)$ \\
\hline Human skin & $29(14.15)$ & $176(85.85)$ \\
\hline Animal death & $34(16.59)$ & $171(83.41)$ \\
\hline Other problems & $22(10.73)$ & $183(89.27)$ \\
\hline Heavy rainfall at planting & $48(23.41)$ & $157(76.59)$ \\
\hline Low rainfall at planting & $14(6.83)$ & $191(93.17)$ \\
\hline Absent of rainfall at flowering / pod seed setting & $28(13.66)$ & $177(86.34)$ \\
\hline Heavy rainfall at harvest & $51(24.88)$ & $154(75.12)$ \\
\hline High rainfall at flowering seed setting & $64(31.22)$ & $141(68.78)$ \\
\hline Other manifestation of rainfall & $101(49.27)$ & $104(50.73)$ \\
\hline Unseasonal rainfall & $13(6.34)$ & $192(93.66)$ \\
\hline
\end{tabular}

Source: survey results, 2016

American Research Journal of Business and Management 
Effect of Climate Change on Agricultural Technologies and Determinants of Adaptation Strategies by Small-holder Farmers in Benishangul-Gumuz Regional State of Ethiopia

Farmers' perception regarding climate change effects are presented at the following table. The major effects of climate change were hotness of the body (55.61\%), further manifestation of rainfall (erratic and heavy rainfall during shower season) (49.27\%), changing the environment (deforestation and wild fire $(33.17 \%)$ ), heavy rainfall during flowering and seed setting (31.22\%) and excessive heating (30.73\%).

Table5. Perception of farmers' on climate change total loss (percentage) on crop and livestock

\begin{tabular}{|c|c|c|c|}
\hline Components of Climate change & Observation & Mean $\mathbf{\pm}$ Std.dev & Max \\
\hline Increased precipitation & 205 & $39.31 \pm 28.64$ & 100 \\
\hline Decreased Precipitation & 205 & $17.02 \pm 22.89$ & 90 \\
\hline Increased variability in precipitation & 205 & $18.11 \pm 22.78$ & 90 \\
\hline Decreased run-off & 205 & $0.87 \pm 5.83$ & 60 \\
\hline Increase runoff & 205 & $17.38 \pm 23.07$ & 100 \\
\hline Run-off variability & 205 & $6.55 \pm 14.35$ & 65 \\
\hline Increased in temperature & 205 & $12.16 \pm 19.62$ & 75 \\
\hline Decrease in temperature & 205 & $5.20 \pm 13.86$ & 75 \\
\hline Increased risk of droughts & 205 & $19.83 \pm 29.92$ & 100 \\
\hline Crop diseases, insect pests infestation & 205 & $50.56 \pm 27.75$ & 100 \\
\hline Livestock diseases & 205 & $27.10 \pm 33.40$ & 100 \\
\hline
\end{tabular}

Source: survey results, 2016

To measure the effect of climate change we use percentage loss due to the causes of climate change indicators as a proxy. As a result, crop diseases and pests had caused about $50.56 \%$ yield losses; excessive/high rainfall had $39.31 \%$ crop yield losses; livestock diseases cause about $27.1 \%$ livestock death. Moreover, drought ( late rainoffsetting) variability in rainfall, increased run-off due to high rain fall decreased rain-fall and high temperature had caused about $19.83 \%, 18.11 \%, 17.38 \%, 17.02 \%$ and $12.16 \%$ yield losses, respectively.

\section{Farmers Perception about Climate Variations}

The farmers' perception regarding the long term perception on climate indicators showed that about $46.83 \%$ and $41.95 \%$ of the respondents revealed that increase in precipitation, increase in disease and insect pests, respectively. However, it must be noted that majority of the farmers do not respond and replied only Almighty God knows about the future.

Table6. Farmers long term perception on climate indicators

\begin{tabular}{|l|l|l|l|l|l|}
\hline \multirow{2}{*}{ Variable } & \multicolumn{5}{|l|}{ Perception/future expectation (percent) } \\
\cline { 2 - 6 } & No response & High & Low & same & Do not know \\
\hline Increase in precipitation in the future & 4.88 & 46.83 & 6.83 & 2.44 & 39.02 \\
\hline Decrease on precipitation & 17.07 & 4.39 & 16.59 & 1.95 & 60.00 \\
\hline Variability in precipitation & 13.66 & 13.17 & 9.76 & 2.93 & 60.49 \\
\hline Increase in runoff & 19.51 & 3.90 & 13.17 & 2.44 & 60.98 \\
\hline Decrease in runoff & 22.93 & 2.44 & 5.37 & 3.41 & 65.85 \\
\hline Increase in flooding & 20.98 & 2.44 & 5.85 & 29.27 & 67.80 \\
\hline Decrease in flood & 25.85 & 0.49 & 2.93 & 3.41 & 67.32 \\
\hline Increase in drought & 91.71 & 5.85 & 0.49 & 0.98 & 0.98 \\
\hline Decrease in drought & 26.83 & 0.49 & 2.44 & 2.93 & 67.32 \\
\hline Increase in temperature & 18.54 & 18.05 & 2.93 & 4.88 & 55.61 \\
\hline Decrease in temperature & 22.44 & 4.88 & 3.90 & 1.46 & 67.32 \\
\hline Increase in diseases, insect pests infestation & 3.90 & 41.95 & 11.71 & 2.44 & 40.00 \\
\hline
\end{tabular}

Source: survey results, 2016 
Effect of Climate Change on Agricultural Technologies and Determinants of Adaptation Strategies by Small-holder Farmers in Benishangul-Gumuz Regional State of Ethiopia

\section{Effect of Climate Change on Improved Agricultural Technologies}

Improved crop and forage varieties have contributions to mitigate climate change. As a result, released agricultural technologies needs to be resistance to climate variability, diseases outbreak, and other biotic and abiotic factors. The national and regional research institutes have released different crops and forage varieties and adopted by smallholder farmers.

Among the mainly used improved varieties of maize were BH-540, BH-660, BH-140, BH-543 and Shone varieties. Accordingly, Shone were less sensitive to climate variability relative to other varieties. Moreover, $\mathrm{BH}-$ 543 was highly susceptible to climate variability followed by BH-140 and BH-660 and 540 respectively. This could be further explained that $\mathrm{BH}-140$ and $\mathrm{BH}-543$ were highly susceptible to strike virus and blight and BH-540 was susceptible to wind and heavy rain. Consequently, we suggest that during technology generation process farmers should participated in technology selection and evaluation to consider their needs. The same interpretation goes to other crop improved varieties as indicated in the table below. The table 7 below further indicates among the respective adopted improved varietieschickpea (Natole), potato (Gudene), groundnut (maniuter), Soybean and forage (Rhodes) were less sensitive to climate variability.

Table7. Farmers response on sensitivity of Agricultural Technologies to climate change

\begin{tabular}{|c|c|c|c|c|c|c|}
\hline \multirow{2}{*}{ Crop Type } & \multirow{2}{*}{$\begin{array}{l}\text { Type of Technology } \\
\text { used }\end{array}$} & \multicolumn{4}{|l|}{ Sensitivity } & \multirow{2}{*}{ Total } \\
\hline & & Very sensitive & Sensitive & Slightly sensitive & Not sensitive & \\
\hline \multirow{5}{*}{ Maize } & BH-540 & 33.33 & 30.56 & 25.00 & 11.11 & 100.00 \\
\hline & BH-660 & 41.67 & 25.00 & 25.00 & 8.33 & 100.00 \\
\hline & BH-140 & 50.00 & 50.00 & 0.00 & 0.00 & 100.00 \\
\hline & Shone & 16.39 & 8.20 & 27.87 & 47.54 & 100.00 \\
\hline & BH-543 & 100.00 & 0.00 & 0.00 & 0.00 & 100.00 \\
\hline Teff & Kuncho & 26.09 & 26.09 & 39.13 & 8.70 & 100.00 \\
\hline \multirow{2}{*}{ Wheat } & Dandaa & 41.67 & 33.33 & 16.67 & 8.33 & 100.00 \\
\hline & \begin{tabular}{|l|} 
Digalu \\
\end{tabular} & 16.67 & 16.67 & 25.00 & 41.67 & 100.00 \\
\hline Finger Millet & Padet & 0.00 & 71.43 & 14.29 & 14.29 & 100.00 \\
\hline Soybean & Belesa-95 & 16.92 & 23.08 & 24.62 & 35.38 & 100.00 \\
\hline Pepper & Marakofana & 80.00 & 20.00 & 0.00 & 0.00 & 100.00 \\
\hline Rice & NERICA-4 & 40.00 & 20.00 & 40.00 & 0.00 & 100.00 \\
\hline \multirow{2}{*}{ Chick pea } & Habru & 35.71 & 42.86 & 14.29 & 7.14 & 100.00 \\
\hline & Natole & 0.00 & 0.00 & 0.00 & 100.00 & 100.00 \\
\hline Groundnut & Maniputer & 57.14 & 0.00 & 0.00 & 42.86 & 100.00 \\
\hline Potato & Gudene & 0.00 & 0.00 & 0.00 & 100.00 & 100.00 \\
\hline \multirow{2}{*}{ Forage } & Oat & 0.00 & 0.00 & 100.00 & 0.00 & 100.00 \\
\hline & Rhodes & 0.00 & 33.33 & 33.33 & 33.33 & 100.00 \\
\hline \multirow{2}{*}{ Bio-fert } & Legume fix & 100.00 & 0.00 & 0.00 & 0.00 & 100.00 \\
\hline & Mar-1492 & 0.00 & 100.00 & 0.00 & 0.00 & 100.00 \\
\hline
\end{tabular}

Source: survey results, 2016

\section{Use of Improved Technologies Adoption}

The major crop technologies adopted were maize, soybean, and wheat. Table below indicates that about $26.42 \%$, $15.33 \%$ and $4 \%$ of yield advantage has been gained due to maize, soybean and wheat varieties adoption, respectively for the sampled households. 
Effect of Climate Change on Agricultural Technologies and Determinants of Adaptation Strategies by Small-holder Farmers in Benishangul-Gumuz Regional State of Ethiopia

Table8. Type of improved varieties, area and change in yield

\begin{tabular}{|l|l|l|}
\hline Crop technology used & Area (in ha) and yield (\%) change & Mean \\
\hline \multirow{4}{*}{ Improved maize varieties } & Area in 2013/14 & 0.24 \\
\cline { 2 - 3 } & Area in 2014/15 & 0.30 \\
\cline { 2 - 3 } Improved soybean varieties & Change in yield due to adoption & 26.42 \\
\hline \multirow{3}{*}{ Improved teff varieties } & Area in 2013/14 & 0.11 \\
\cline { 2 - 3 } & Area in 2014/15 & 0.15 \\
\cline { 2 - 3 } & Change in yield due to adoption & 15.33 \\
\hline \multirow{3}{*}{ Improved wheat varieties } & Area in 2013/14 & 0.03 \\
\cline { 2 - 3 } & Area in 2014/15 & 0.04 \\
\cline { 2 - 3 } & Change in yield due to adoption & 2.90 \\
\hline \multirow{3}{*}{ Improved chickpea varieties } & Area in 2013/14 & 0.04 \\
\cline { 2 - 3 } & Area in 2014/15 & 0.05 \\
\cline { 2 - 3 } & Change in yield due to adoption & 4.0 \\
\hline & Area in 2013/14 & 0.01 \\
\cline { 2 - 3 } & Area in 2014/15 & 0.01 \\
\cline { 2 - 3 } & Change in yield due to adoption & 0.53 \\
\hline & Area in 2013/14 & 0.005 \\
\cline { 2 - 3 } & Area in 2014/15 & 0.01 \\
\cline { 2 - 3 } & Change in yield due to adoption & 1.31 \\
\hline
\end{tabular}

Source: survey results, 2016

\section{Farmers Adaptation strategies}

Table below represents various adaptation strategies being used by farmers in response to changing climatic and other socio-economic factors based on the survey observations. Regardless of whether the farmers are aware of climate change or not almost all of the farmers adopts adaptation strategies. These includes increased diversification and escaping sensitive growth stages through crop management practices that ensure critical crop growth stage do not coincide with very harsh climatic conditions in the season such as excess rainfall, high temperature, pests and disease prevalence and post-harvest losses and changing factors of production like land, labour and capital.

Increased diversification not only through engaging in production activities that are more drought-tolerant and or resistant to temperature stresses but also excessive rainfall tolerant as well as activities that make efficient use and take full advantage of prevailing water serve as an important form of adaptation strategy against climatic condition variability. Moreover, cultivating a number of different crops in the same plot or in different plots were effective in reducing the risk of complete crop failure as different crops are affected differently by climate events.

Table9. Major climate change adaptation measures taken by farmers and their effectiveness

\begin{tabular}{|l|l|l|l|l|l|l|l|}
\hline \multirow{2}{*}{ Adaptation measure } & \multicolumn{3}{|l|}{ Implemented } & \multicolumn{3}{l|}{$\begin{array}{l}\text { Effectiveness of the } \\
\text { adaptation measures }\end{array}$} \\
\cline { 2 - 7 } & No & Yes & Worse & same & $\begin{array}{l}\text { Slightly } \\
\text { better }\end{array}$ & $\begin{array}{l}\text { Much } \\
\text { better }\end{array}$ \\
\hline $\begin{array}{l}\text { Use of local Sorghum varieties during drought/rainfall } \\
\text { shortage }\end{array}$ & 94.15 & 5.85 & 0.00 & 0.00 & 100.00 & 0.00 \\
\hline $\begin{array}{l}\text { Reduction in Fertilizer application rate during high } \\
\text { temperature }\end{array}$ & 92.68 & 7.32 & 0.00 & 6.67 & 66.67 & 26.67 \\
\hline Use of local Sorghum varieties during high temperature & 92.68 & 7.32 & 0.00 & 6.67 & 86.67 & 6.67 \\
\hline
\end{tabular}

American Research Journal of Business and Management 
Effect of Climate Change on Agricultural Technologies and Determinants of Adaptation Strategies by Small-holder Farmers in Benishangul-Gumuz Regional State of Ethiopia

\begin{tabular}{|l|l|l|l|l|l|l|}
\hline Pest and disease prevalence protection using chemical spray & 54.41 & 45.59 & 1.08 & 5.38 & 29.03 & 64.52 \\
\hline $\begin{array}{l}\text { Pest and disease prevalence protection using cultural } \\
\text { practices }\end{array}$ & 49.27 & 50.73 & 0.00 & 3.85 & 50.00 & 46.15 \\
\hline $\begin{array}{l}\text { Use of long maturing improved maize varieties during } \\
\text { heavy rain season }\end{array}$ & 95.61 & 4.39 & 0.00 & 0.00 & 33.33 & 66.67 \\
\hline $\begin{array}{l}\text { Use of long maturing local sorghum varieties during heavy } \\
\text { rain season }\end{array}$ & 89.27 & 10.73 & 0.00 & 0.00 & 45.45 & 54.55 \\
\hline Using ridges for heavy rain/flood protection & 35.12 & 64.88 & 0.00 & 1.50 & 40.60 & 57.89 \\
\hline Post-harvest losses management using chemicals & 23.41 & 76.59 & 0.00 & 3.82 & 23.57 & 72.61 \\
\hline Post-harvest losses management using local treatments & 42.44 & 57.56 & 0.00 & 4.24 & 49.15 & 46.61 \\
\hline Using different crop improved varieties & 60.00 & 40.00 & 2.44 & 2.44 & 42.68 & 52.44 \\
\hline Crop diversification & 45.59 & 54.41 & 0.00 & 0.90 & 47.75 & 51.35 \\
\hline Using different planting date & 60.78 & 39.22 & 0.00 & 2.50 & 42.50 & 55.00 \\
\hline Diversifying from farm to nonfarm activities & 84.39 & 15.61 & 0.00 & 6.25 & 53.13 & 40.63 \\
\hline Increased use of irrigation and ground water & 53.17 & 46.83 & 1.04 & 4.17 & 46.88 & 47.92 \\
\hline Water and soil conservation techniques & 59.51 & 40.49 & 0.00 & 1.20 & 60.24 & 38.55 \\
\hline Shortening of growing season & 78.05 & 21.95 & 0.00 & 0.00 & 77.78 & 22.22 \\
\hline Lengthening of growing season & 80.49 & 19.51 & 4.76 & 2.38 & 71.43 & 21.43 \\
\hline Shifting cultivation & 85.37 & 14.63 & 0.00 & 6.67 & 56.67 & 36.67 \\
\hline Changing quantity of land under cultivation & 71.71 & 28.29 & 1.72 & 5.17 & 62.07 & 31.03 \\
\hline Changing use of capital and labor & 76.10 & 23.90 & 8.16 & 2.04 & 53.06 & 36.73 \\
\hline Changing use of chemical fertilizer & 68.29 & 31.71 & 0.00 & 0.00 & 61.54 & 38.46 \\
\hline Water Conservation techniques & 75.12 & 24.88 & 0.00 & 0.00 & 80.39 & 19.61 \\
\hline Soil conservation techniques & 65.85 & 34.15 & 0.00 & 2.86 & 54.29 & 42.86 \\
\hline Ritual offering or prayer & 39.02 & 60.98 & 2.40 & 0.00 & 32.00 & 65.60 \\
\hline
\end{tabular}

Source: survey results, 2016

Farmers are using crop management practices such as use of irrigation, water and soil conservation techniques and varying planting dates to ensure that critical, sensitive growth stages do not coincide with very harsh climatic conditions in the season. These strategies can also be used to modify length of the growing season and shorten growing season; for instance irrigation and water conservation techniques are an important source of additional water that can be used to lengthen the growing period of crops. Moreover, growing early maturing crops can also be used to shorten the growth period and escape the short rainfall seasons for soil moisture stress areas. It is important to note these adaptation measures should not be taken as independent strategies but should be used in a complementary way as indicated interaction matrix of the correlation coefficients.

\section{Determinants of Adaptation Measures to Climate Change}

As we already justified at the methodology part, the study estimated a multivariate probit model for each of the eight adaptation options. Results from the multivariate probit model of determinants of adaptation measures are presented in table 10. The results of the correlation coefficients of the error terms are significant (based on the t-test statistic) for any pairs of equations indicating that they are correlated. The results on correlation coefficients of the error terms indicate that there are complementarities (positive correlation) between different 
Effect of Climate Change on Agricultural Technologies and Determinants of Adaptation Strategies by Small-holder Farmers in Benishangul-Gumuz Regional State of Ethiopia

adaptation options being used by farmers. The results supports the assumption of interdependence between the different adaptation options which may be due to complementarity in the different adaptation options and also from omitted household-specific and other factors that affect uptake of all the adaptation options. Another important point to note from the results is that there are substantial differences in the estimated coefficients across equations that support the appropriateness of differentiating between adaptation options.

The chi-square $(\chi 2)$ distribution is used as the measure of overall significance of a model inmultivariate probit model estimation. The variables included explaining climate change strategies fits best the model at less than $1 \%$ probability level. This implies that the joint null hypothesis of coefficients of all explanatory variables included in the model were zero should be rejected. The multivariate probit model presented in table 10 was estimated to identify factors that affect the decision to participate in climate change strategies and it's the interdependence of the choice decisions (Lin et al., 2004; Beldberboset al., 2004).

Dependency ratio had a significant and negative effect on the likelihood of participation decision in the climate adaptation optionsand adoption different improved varieties specifically adoption of different improved crop varieties as expected. Thus, economically active household members significantly affect the decision of adoption of improved crop varieties. The coefficient for the aggregate model is significant at $1 \%$ probability level. The coefficient of -1.5 suggests that if the household productive labor size increases by one percent, the likelihood to adopt different crop improved varieties increases by 150 percent while holding all other variables in the model constant. This may be due to the behavior of agricultural activities (crop production) is labor intensive where households with more family labor could adopt different improved varieties as improved varieties demand good management practices to give the expected outputs.

Family size had a significant and positive effect on the likelihood of participation decision in the climate adaptation option i.e. to use irrigation. This may be the due to households with large family size would have enough labour for irrigation and rain-fed agricultural activities.Total land ownership increases the probability of adoption of different improved crop varieties and changing capital and labour at the probability of 0.05 . It seems logical as farmers with large land are likely to have more advantage to adopt different improved varieties and due to the increased demand in agriculture as a business have changed the use of capital and labour as large parcel of lands requires more capital and labour due to change in climatic conditions and crop management practices. Land is the main factor of production in farming and farmers with large land ownership have high likelihoods to adopt and test different crop varieties and use capital and labour to cultivate high yielding, resistance to diseases and insect pests and adaptable to climatic conditions.

Farmers with access to credit have higher chances of adapting to changing climatic conditions. Access to affordable credit increases financial resources of farmers and their ability to meet transaction costs associated with the various adaptation options they might want to take. With more financial and other resources at their disposal farmers are able to change their management practices in response to changing climatic and other factors and are better able to make use of all the available information they might have on changing conditions both climatic and other socioeconomic factors. Hence, use of irrigation, changing capital and labour, use of chemicals to protect diseases, insect and pests and adjustment in planting dates were significantly and positively affected by access to credit. This may be due to the fact that accesses to financial resources would able to buy farm chemicals, new irrigation technologies, and other important inputs and machineries that may need to change their practices to suit the forecasted and prevailing climatic conditions. The important policy implication is that access to financial resources would enable farmers to use alternative farming system options like switching from rain-fed agriculture to irrigated one and or using both types of agricultural systems and this in turn would able them to create capacity to adjustment capital and labour and use of different planting dates.

American Research Journal of Business and Management Page 11 
Effect of Climate Change on Agricultural Technologies and Determinants of Adaptation Strategies by Small-holder Farmers in Benishangul-Gumuz Regional State of Ethiopia

Table10. Household-level climate change adaptation strategies and its determinants

\begin{tabular}{|c|c|c|c|c|c|c|c|c|}
\hline \multirow{4}{*}{ Variables } & \multicolumn{8}{|c|}{ Climate change Adaptation Strategies } \\
\hline & (1) & $(2)$ & (3) & $(4)$ & (5) & (6) & (7) & $(8)$ \\
\hline & CD & IRR & DIFIM & LANDC & CKL & CHSP & RIDG & DIFPLD \\
\hline & \begin{tabular}{|l|} 
Coef \\
(Std.Err)
\end{tabular} & $\begin{array}{l}\text { Coef (Std. } \\
\text { Err) }\end{array}$ & \begin{tabular}{|l|} 
Coef (Std. \\
Err)
\end{tabular} & \begin{tabular}{|l|} 
Coef \\
(Std.Err)
\end{tabular} & $\begin{array}{l}\text { Coef } \\
\text { (Std.Err) }\end{array}$ & \begin{tabular}{|l} 
Coef \\
(Std.Err)
\end{tabular} & \begin{tabular}{|l|} 
Coef \\
(Std.Err)
\end{tabular} & \begin{tabular}{|l} 
Coef \\
(Std.Err)
\end{tabular} \\
\hline Dependence ratio & $\begin{array}{l}-0.73 \\
(0.45)\end{array}$ & $\begin{array}{l}0.64 \\
(0.46)\end{array}$ & $\begin{array}{l}-1.5^{* * *} \\
(0.45)\end{array}$ & \begin{tabular}{|l|}
-0.25 \\
$(0.46)$
\end{tabular} & $\begin{array}{l}-0.32 \\
(0.51)\end{array}$ & \begin{tabular}{|l|}
-0.64 \\
$(0.43)$
\end{tabular} & $\begin{array}{l}0.34 \\
(0.45)\end{array}$ & \begin{tabular}{|l|}
-0.19 \\
$(0.46)$
\end{tabular} \\
\hline Total. Land (ha) & $\begin{array}{l}0.06 \\
(0.04) \\
\end{array}$ & \begin{tabular}{|l|}
-0.07 \\
$(0.05)$ \\
\end{tabular} & $\begin{array}{l}0.11^{* *} \\
(0.04)\end{array}$ & $\begin{array}{l}0.08 \\
(0.05) \\
\end{array}$ & $\begin{array}{l}0.09 * * \\
(0.05)\end{array}$ & $\begin{array}{l}-0.01 \\
(0.04) \\
\end{array}$ & $\begin{array}{l}-0.01 \\
(0.04) \\
\end{array}$ & \begin{tabular}{|l|}
0.07 \\
$(0.04)$ \\
\end{tabular} \\
\hline $\begin{array}{l}\text { Cooperative } \\
\text { Membership }\end{array}$ & $\begin{array}{l}0.45^{*} \\
(0.25) \\
\end{array}$ & $\begin{array}{l}0.001 \\
(0.26) \\
\end{array}$ & $\begin{array}{l}0.21 \\
(0.24) \\
\end{array}$ & $\begin{array}{l}0.42^{*} \\
(0.25) \\
\end{array}$ & $\begin{array}{l}-0.07 \\
(0.26) \\
\end{array}$ & \begin{tabular}{|l|}
0.33 \\
$(0.24)$ \\
\end{tabular} & $\begin{array}{l}0.32 \\
(0.25) \\
\end{array}$ & $\begin{array}{l}0.48^{* *} \\
(0.24) \\
\end{array}$ \\
\hline Credit access & $\begin{array}{l}0.06 \\
(0.23) \\
\end{array}$ & $\begin{array}{l}0.61^{* * *} \\
(0.23)\end{array}$ & $\begin{array}{l}0.35 \\
(0.23) \\
\end{array}$ & $\begin{array}{l}0.39^{*} \\
(0.23)\end{array}$ & $\begin{array}{l}0.58^{* *} \\
(0.25)\end{array}$ & $\begin{array}{l}0.49^{* *} \\
(0.22) \\
\end{array}$ & $\begin{array}{l}0.38 \\
(0.23) \\
\end{array}$ & $\begin{array}{l}0.45^{* *} \\
(0.23) \\
\end{array}$ \\
\hline Family size & $\begin{array}{l}0.01 \\
(0.03) \\
\end{array}$ & $\begin{array}{l}0.08^{* *} \\
(0.03) \\
\end{array}$ & $\begin{array}{l}0.006 \\
(0.03) \\
\end{array}$ & \begin{tabular}{|l|}
-0.04 \\
$(0.04)$ \\
\end{tabular} & $\begin{array}{l}0.03 \\
(0.04)\end{array}$ & \begin{tabular}{|l|}
-0.03 \\
$(0.03)$ \\
\end{tabular} & $\begin{array}{l}0.04 \\
(0.03) \\
\end{array}$ & $\begin{array}{l}0.05 \\
(0.03) \\
\end{array}$ \\
\hline Bambasi & $\begin{array}{l}0.74^{* *} \\
(0.31) \\
\end{array}$ & $\begin{array}{l}1.74^{* * *} \\
(0.46) \\
\end{array}$ & $\begin{array}{l}-0.28 \\
(0.31) \\
\end{array}$ & \begin{tabular}{|l|}
0.40 \\
$(0.32)$ \\
\end{tabular} & $\begin{array}{l}0.52 \\
(0.36) \\
\end{array}$ & $\begin{array}{l}0.72^{* *} \\
(0.31) \\
\end{array}$ & \begin{tabular}{|l}
$0.93^{* * *}$ \\
$(0.31)$ \\
\end{tabular} & \begin{tabular}{|l|} 
\\
$(0.48$ \\
\end{tabular} \\
\hline Mao-Komo & $\begin{array}{l}0.63^{*} \\
(0.33)\end{array}$ & $\begin{array}{l}1.63^{* * *} \\
(0.46)\end{array}$ & $\begin{array}{l}0.61^{*} \\
(0.33)\end{array}$ & $\begin{array}{l}0.21 \\
(0.35)\end{array}$ & $\begin{array}{l}-0.04 \\
(0.41)\end{array}$ & $\begin{array}{l}0.51 \\
(0.31)\end{array}$ & $\begin{array}{l}0.44 \\
(0.32)\end{array}$ & $\begin{array}{l}0.45 \\
(0.35) \\
\end{array}$ \\
\hline $\begin{array}{l}\text { No. of extension. } \\
\text { visits }\end{array}$ & $\begin{array}{l}0.03^{*} \\
(0.016)\end{array}$ & $\begin{array}{l}-0.001^{*} \\
(0.013)\end{array}$ & $\begin{array}{l}0.03^{* *} \\
(0.02)\end{array}$ & $\begin{array}{l}-0.012 \\
(0.016)\end{array}$ & $\begin{array}{c}-0.004 \\
(0.05)\end{array}$ & $\begin{array}{l}-0.005 \\
(0.013)\end{array}$ & $\begin{array}{l}0.013 \\
(0.026)\end{array}$ & $\begin{array}{l}0.016 \\
(0.013)\end{array}$ \\
\hline $\begin{array}{l}\text { Distance to } \\
\text { extension office } \\
(\mathrm{km})\end{array}$ & $\begin{array}{l}0.01 \\
(0.07)\end{array}$ & $0.10(0.07)$ & $\begin{array}{l}0.007 \\
(0.07) \\
\end{array}$ & $\begin{array}{l}0.08 \\
(0.07) \\
\end{array}$ & $\begin{array}{l}0.21^{* * *} \\
(0.08)\end{array}$ & $\begin{array}{l}-0.04 \\
(0.07) \\
\end{array}$ & $\begin{array}{l}0.073 \\
(0.072) \\
\end{array}$ & $\begin{array}{l}0.16^{* *} \\
(0.07)\end{array}$ \\
\hline $\begin{array}{l}\text { Distance to market } \\
(\mathrm{km})\end{array}$ & $\begin{array}{l}-0.50 \\
(0.31) \\
\end{array}$ & $\begin{array}{l}-0.047^{* *} \\
(0.02) \\
\end{array}$ & $\begin{array}{l}-0.03^{*} \\
(0.02) \\
\end{array}$ & $\begin{array}{l}0.002 \\
(0.018) \\
\end{array}$ & $\begin{array}{l}0.004 \\
(0.02) \\
\end{array}$ & $\begin{array}{ll}-0.01 \\
(0.02) \\
\end{array}$ & \begin{tabular}{|l|}
-0.01 \\
$(0.016)$
\end{tabular} & $\begin{array}{l}-0.001 \\
(0.018) \\
\end{array}$ \\
\hline Farming system & $\begin{array}{l}-0.11 \\
(0.25) \\
\end{array}$ & $-0.16(0.28)$ & \begin{tabular}{|l|}
-0.002 \\
$(0.27)$ \\
\end{tabular} & \begin{tabular}{|l|}
-0.07 \\
$(0.26)$ \\
\end{tabular} & $\begin{array}{l}1.01^{* * *} \\
(0.36) \\
\end{array}$ & \begin{tabular}{|l|}
0.04 \\
$(0.25)$ \\
\end{tabular} & $\begin{array}{l}.36 \\
(0.25) \\
\end{array}$ & \begin{tabular}{|l|}
0.40 \\
$(0.26)$ \\
\end{tabular} \\
\hline $\begin{array}{l}\text { Fertilizer use } \\
\text { experience (years) }\end{array}$ & $\begin{array}{l}0.07^{* * *} \\
(0.02) \\
\end{array}$ & $\begin{array}{l}-0.02 \\
(0.026) \\
\end{array}$ & $\begin{array}{l}0.023 \\
(0.024) \\
\end{array}$ & $\begin{array}{l}0.008 \\
(0.03) \\
\end{array}$ & $\begin{array}{l}0.005 \\
(0.03)\end{array}$ & $\begin{array}{l}0.04^{*} \\
(0.02) \\
\end{array}$ & $\begin{array}{l}0.004 \\
(0.04) \\
\end{array}$ & $\begin{array}{l}-0.03 \\
(0.023) \\
\end{array}$ \\
\hline $\begin{array}{l}\text { Post-harvest } \\
\text { technology use } \\
\text { and experience } \\
\text { (years) }\end{array}$ & $\begin{array}{l}-0.01 \\
(0.02)\end{array}$ & $0.01(0.02)$ & $\begin{array}{l}0.07^{* * *} \\
(0.02)\end{array}$ & $\begin{array}{l}0.07^{* * *} \\
(0.03)\end{array}$ & $\begin{array}{l}0.03^{*} \\
(0.02)\end{array}$ & $\begin{array}{l}0.013 \\
(0.015)\end{array}$ & $\begin{array}{l}-0.02^{*} \\
(0.015)\end{array}$ & $\begin{array}{l}-0.004 \\
(0.015)\end{array}$ \\
\hline _Const & $\begin{array}{l}-0.55 \\
(0.44) \\
\end{array}$ & $\begin{array}{l}-2.2^{* * *} \\
(0.58) \\
\end{array}$ & $\begin{array}{l}-0.43 \\
(0.42) \\
\end{array}$ & $\begin{array}{l}-.86 \\
(0.45) \\
\end{array}$ & $\begin{array}{l}-2.6^{* * *} \\
(0.58) \\
\end{array}$ & \begin{tabular}{|l|}
-0.58 \\
$(0.43)$ \\
\end{tabular} & $\begin{array}{l}-1.12^{* *} \\
(0.45)\end{array}$ & $\begin{array}{l}2.0^{* * *} \\
(0.49) \\
\end{array}$ \\
\hline $\begin{array}{l}\text { Predicted } \\
\text { probability }\end{array}$ & 0.54 & 0.46 & 0.40 & 0.27 & 0.23 & 0.45 & 0.64 & 0.38 \\
\hline
\end{tabular}

\begin{tabular}{|l|l|l|l|l|l|l|l|l|}
\hline rho21 & -0.067 & rho32 & 0.102 & rho43 & $0.400^{* * *}$ & rho54 & $0.563^{* * *}$ & \multirow{2}{*}{ rho87 =0.181 } \\
\hline rho31 & $0.764^{* * *}$ & rho42 & $0.195^{*}$ & rho53 & $0.352^{* * *}$ & rho64 & 0.104 & \\
\hline rho41 & $0.320^{* *}$ & rho52 & -0.104 & rho63 & 0.168 & rho74 & $0.215^{*}$ & \\
\hline rho51 & $0.265^{*}$ & rho62 & -0.131 & rho73 & $0.287^{* *}$ & rho84 & $0.206^{* * *}$ & \\
\hline rho61 & 0.022 & rho72 & 0.006 & rho83 & $0.255^{* *}$ & rho76 & 0.149 & \\
\hline
\end{tabular}


Effect of Climate Change on Agricultural Technologies and Determinants of Adaptation Strategies by Small-holder Farmers in Benishangul-Gumuz Regional State of Ethiopia

\begin{tabular}{|l|l|l|l|l|l|l|l|l|}
\hline \hline rho71 & 0.084 & rho82 & 0.006 & rho65 & 0.179 & rho86 & $0.307^{* * *}$ & \\
\hline rho81 & $0.289^{* * *}$ & rho75 & 0.206 & rho75 & 0.206 & rho85 & $0.306^{* *}$ & \\
\hline Observations & 204 & Prob>Chi2 & 0.0000 & \\
\hline Log likelihood & $(831.88)$ & Joint probability of success & 0.02 & \\
\hline Wald chi2 (104) & 240.52 & Joint probability of failure & 0.06 & \\
\hline
\end{tabular}

Source: survey results, 2016

Agro-ecology increases the probability of farmers respond to changes interms of crop diversification,use of irrigation and ground water, use of different improved varieties, management practices. This indicates that have different strategies in response to change in climatic conditions. Therefore, farmers living at humid intermediate and highland agro-ecologies were used different climatic options so as to mitigate impacts of climate change and intervention needs to be done based on the resources endowments and appropriateness of the mitigation strategies across different agro-ecologies. For example, these agro-ecologies have excess rainfall and high temperature. Hence, priority should be given to long maturing varieties development, use of irrigation and ground water to use water resources effectively and efficiently.

Extension visit had significant effect on climate change adaptation options like crop diversification, adoption of improved varieties, and use of irrigation. Farmers with frequently visited by development agents had high likelihood to participate in climate change strategies. However, farmers frequently visited by extension agents were unlikely to participate in irrigation water use. This may be due to the extension contacts may not be necessarily on irrigation rather on rain-fed crop production and another agricultural activities and it implies that extension services on irrigation and water use should be promoted jointly with another extension services.

Distance to grain market and extension services had also an effect on the climate change adaptation options. Therefore, access to market places and access to extension services should give attention in minimizing risks occurred at pre and post-harvest. This could be achieved through expansion of road infrastructure, capacitating and strengthened farmers training centres that would help to foster dissemination and popularization of improved agricultural technologies.

Farmers experience in using fertilizer had an effect on crop diversification adaptation option. Thus, experience on the use of fertilizer could enable farmers to improve the knowledge of farmers on the application rate and fertilizer requirements of their farm plot. Hence, experienced farmers would have better knowledge on the crop fertilizer applications and time of applications. This could finally enable them to adapt to climatic conditions in variable rainfall and temperature changes.

Mixed crop and livestock farmers are associated with positive and significant adaptation tochanges (capital and labour) in climatic conditions compared to specialized crop and or livestock farmers. This may be due to the nature of the mixed farming system which is characterized as for crop production; livestock asset ownership could help to minimize risk in case of crop failure and vice-versa. Moreover, the two types of enterprises are complements each other in many cases. Consequently, the results implythat mixed farming systems are better able to cope with changes to climatic conditions throughundertaking various changes in production practices.

Farmers experience in using post-harvest technologies had an effect to up take different climate adaptation options. This could be due to the fact that as farmers experience in farming increased the use of post-harvest techniques and technologies would be enhanced. Furthermore, as use of post-harvest technologies experience is increased; adoption of improved varieties would be enhanced as the farmers' knowledge and skills in pre harvest and post-harvest management is improved.For instance, the use of irrigation technologies needs to be accompanied by other good crop management practices such as use of crops with better use of water; use of efficient irrigation systems, growing crops that require less water and using improved irrigation water use practices.

American Research Journal of Business and Management

Page 13 
Effect of Climate Change on Agricultural Technologies and Determinants of Adaptation Strategies by Small-holder Farmers in Benishangul-Gumuz Regional State of Ethiopia

\section{Interactions of Climate Change Adaptation Decisions}

The interdependence of climate change adaptation strategies like crop diversification, use of irrigation, adoption of different crop improved varieties, land change, capital and labor change, use of chemical spraying, using soil and water conservation techniques like ridging and changing planting date was accounted for by employing the multivariate probit simulation of the participation decision of the eight adaptation strategies(table9). The null that the correlations are jointly zero and the eight adaptation decisions are independent was rejected at the $1 \%$ significance level. The SML estimation results suggested that there was positive and significance interdependence between households' decisions between crop diversification and adoption of different improved varieties, change in land use, adjustment in planting date and capital and labor change. Moreover, use of irrigation/ground water and change in land use shows that there was positive and significant interaction.

The same result revealed that, change in farm land use, change in capital and labor, soil and water conservation techniques and planting date had positive and significant interaction with adoption of improved crop varieties. This is not actually surprising due the nature of the climate change adaptation option are complements with each other. Land use change had also positive and significant interaction with change in capital and labor, use of soil and water conservation techniques and using different planting date.Moreover, there was positive and significant interaction between adjustments in planting date and use of capital and labor change and use of chemical spray during disease and pests incidence. From the interdependence analysis we found that that the climates change adaptation strategies were complements to each other. Hence, promotion and intervention on one strategy would have a synergetic to reduce the impact of climate change effects.

Table10revealed that the predicted, joint success and failure probabilities of the households' decision to choose the climate change adaptation strategies. The predicted probability (likelihood) of using soil and water conservation techniques like ridging was $64 \%$ which is high comparing to the others. It seems logical, that is probably the area is suffered from excess rainfall and to minimize runoff the farmers may adopt the strategy compared to other climate change adaptation options. The likelihood of decision to choose crop diversification, use of irrigation, adoption of improved varieties, change in land use, change in capital and labour, use of agro-chemical spraying and using different planting date were $54 \%, 46 \%, 40 \%, 27 \%, 23 \%, 45 \%$, and $38 \%$, respectively. The small predicted probability level may indicate that though there is high demand for capital and land use change, due to limited access to land and capital (small amount of credit) the households were less likely to participate in the climate change adaptation options.Furthermore, the joint probability showed that, if households were able to choose all eight strategies, their joint likelihood of choosing these strategies would be only 2 percents. It was unlikely for households to choose all strategies simultaneously. This was justified either by the fact that simultaneous adoption of all the option was impossible for the farmers, or that all the strategies were not simultaneously adopted across the different agro-ecologies.Moreover, the joint probability of not choosing all options by the households was also $6 \%$, implying that the households haveparticipated at least one climate adaptation option. This evidence suggests the need to launch a package and scheme of climate change mitigation strategies based on the resources availability of smallholder farmers.

\section{Conclusions ANd Policy Implications}

\section{Summary and Conclusion}

Adverse climatechange impacts are considered to be particularly strong in areas located in tropical that depend on agriculture as their main source of livelihood. The fact that climate has been changing in the past and continues to change in the future implies the need to understand how farmers perceive climate change and adapt in order to guide strategies for adaptation in the future. Identifying factors influencing farm-level adaptation can facilitate the formation of policies and investment strategies that help moderate potential 
Effect of Climate Change on Agricultural Technologies and Determinants of Adaptation Strategies by Small-holder Farmers in Benishangul-Gumuz Regional State of Ethiopia

adverse consequences of longtermclimate change. Because smallholder farmers tend to have a low capacity to adapt to changes in climatic conditions, policies that help these farmers adapt to global warming and associated climatic extremes are particularly important. A better understanding of the local dimensions of adaptation is therefore essential to develop appropriate adaptation measures that will mitigate these adverse consequences. The knowledge of the adaptation methods to climatechange enhance policy towards tackling the challenges that climate change is imposing onsmallholder farmers. In relation to this, the study attempted to identify factors affecting the choice of climate change adaptation strategies by smallholder farmers in selected districts of Benishangul Gumuz region, western Ethiopia.

The data were collected from a total of 204 sampled household heads.Descriptive statistics were used to provide insights into farmers' perception of climate change,types of adaptation strategies to climate change and to explain factors affecting farm levelclimate change adaptation strategies.

The farmer perceptions about the long term climatic change variations were analyzed using descriptive statistics. The results indicate that the perception of farmers on long term change in temperature and precipitations is high. This indicates that the study areas are getting warmer complemented with high precipitation. Consequently, the farmers need to adjust their crop management practices and research endeavours must targeted at generating heat and precipitation tolerant crop varieties. Moreover, the descriptive statistics results confirmed that crop technologies adaption has reduced losses due to climate change relatively to the non-adopters.

Important adaptation options being used by farmers include crop diversification, using different improved crop varieties, changing planting and harvesting dates, increased use of irrigation, increased use of waterand soil conservation techniques, changing planting dates, and changing land under cultivation, capital and labour. The adaptationoptions being used by farmers can be classified into three main modifications in the production systems i.e., increased diversification, escaping sensitive growth stages through crop management practices thatensure that critical crop growth stages do not coincide with very harsh climatic conditions and changing factors of production. Increased diversification through engaging in production activities that improve efficient use of available water resources and resistant to temperature stresses is very crucial. Growing a number of different crops in the same plot or different plots reduces the risk of complete crop failure as different crops are affecteddifferently by climate events.

It is important to note that these adaptation measures should be taken in a complementary way as one adaptation strategy has a synergetic effect on another strategy. Supporting farmers in increasing these adaptation measures through providing the necessary resources such as land, credit, providing adequate extension services and information and training on pre and post-harvest technologies can significantly help farmers increase and sustain high productivity levels evenunder changing climatic conditions.

The paper explored the determinants of household use of different adaptation measures using amultivariate probit model. The correlationresults between error terms of different equations were significant (positive) indicating that variousadaptation options tend to be used by households in a complementary fashion, although this could also bedue to unobserved household socioeconomic and other factors. The econometric results confirm that access to credit, extension services, membership in farmers club, family size, fertilizer use experience and mixed crop and livestock farms, land ownership, experience on using post-harvest technologies of the important determinants of household level adaptation options. Use of different adaptation measuressignificantly increase for household with more access to these factors. Designing policies that aim toimprove these factors for smallholder farming systems have great potential to improve farmer adaptationto changes in climate. For example, more access to credit facilities, land as well as access to grain markets and agricultural input providers) can significantly increase farm level adaptation.

American Research Journal of Business and Management Page 15 
Effect of Climate Change on Agricultural Technologies and Determinants of Adaptation Strategies by Small-holder Farmers in Benishangul-Gumuz Regional State of Ethiopia

\section{Policy Implications}

Based on the evidences found from this finding, there is a need for urgent action aimed ataddressing the causes of climate change adaptation strategies in the study area. These may includethe following:

- Government policies need to support research and development that develops and diffuses the appropriatetechnologies to help farmers adapt to changesin climatic conditions. Government responsibilities areusually through conscious policy measures to enhance the adaptive capacity of agricultural systems. Examples of these policy measures include crop technologies resistant to rainfall variability and high temperature, promoting farm level adaptation measures, such as efficient use of irrigation and ground water, post-harvesttechnologies.

- Accessibility to key agricultural production information like these water andsoil conservation techniques as well as the other adaptation options identified above is essential inpromoting farmer adaptation to changes in climate.

- Respective stakeholders aimed at promoting farm-level adaptation need to emphasize on the crucial role ofproviding information on better production techniques and enhancing farmers' awarenesson climate change through extension servicesand creating the financial means through affordablecredit provisions to enable small-holder farmers to use different adaptation measures to climate change.

- Policy interventions should focus on encouraging formal (training) and informal social networks (farmerto-farmer extension visits) which increases farmers use of different adaptationstrategies to reduce the negative impact of climate change. Because access to farmer-to farmer extension visits and training ensures that farmers have information for decisionmaking and enhances the experiences of farming activities for better adaptation strategy practices.

- Better access to markets reduces transport and other market related transaction costs and enhances the uptake of farm-level adaptation measures. For instance, better access tomarkets enables farmers to access information, buy new crop varieties, new irrigationtechnologies and other important inputs they may need if they are to change their practicesto cope with predicted changes in future climate. Hence it is necessary to improve farmers'relatively poor access to markets.

\section{REFERENCES}

1. Belderbos R., M. Carree, B. Diederen, B. Lokshin, and R. Veugelers. 2004., Heterogeneity in R\&D cooperation strategies. International Journal of Industrial Organisation22: 1237-1263.

2. Brohan, P., Kennedy, J.J., Harris, I., Tett, S.F.B. and Jones, P.D. (2006). Uncertainty estimates in regional and global observed temperature changes: A new data set from 1850. Journal of Geophysical Research Atmospheres, 111, D12106.

3. Cameron C \& Trivedi TK, 2009. Micro-econometrics using Stata. StataCorp Ltd, Texas, USA.

4. Cappellari, L., \& Jenkins, S., 2003. Multivariate probit regression using simulated maximum likelihood. The Stata Journal, 3(3), 278-294.

5. Chib S \& Greenberg E, 1998. Analysis of multivariate probit models. Biometrika 85(2): 347-61.

6. Crosson, P. (1983). A schematic view of resources, technology and environment in agricultural development. Agriculture, Ecosystems and Environment, 9, 339-357.

7. Degye Goshu, Belay Kassa, and Mengistu Ketema, 2013. Is food security enhanced by agricultural technologies in rural Ethiopia? AfJARE Vol. 8 No. 1, pages 58 - 68, July.

8. Dercon, S. (2004). "Growth and Shocks: Evidence from Rural Ethiopia." Journal of Development Economics 74(2):309-329. 
Effect of Climate Change on Agricultural Technologies and Determinants of Adaptation Strategies by Small-holder Farmers in Benishangul-Gumuz Regional State of Ethiopia

9. Greene WH, 2012. Econometric analysis. Seventh edition. New Jersey: Pearson Hall.

10. Hassan, R., Nhemachena, C. (2008). Determinants of African farmers' strategies for adapting to climate change: Multinomial choice analysis", AfJARE 2: 83-104.

11. Houghton, J. T., Jenkins, G. J., andEphrams, J. J. (1990).IPCC scientific assessment of global climate change. Geneva and Nairobi: World Meteorological Organization and United Nations Environmental Program.

12. Jagtap, S. (2007) Managing vulnerability to extreme weather and climate events: Implications for agriculture and food security in Africa. Proceedings of the International Conference on Climate Change and Economic Sustainability held at NnamdiAzikiwe University, Enugu, Nigeria. 12-14 June 2007.

13. Lin, C-T.J., K.L. Jensen, and S.T. Yen. 2005. Awareness of foodborne pathogens among US consumers. Food Quality and Preference 16: 401-412.

14. Long JS \&Freese J, 2005. Regression models for categorical dependent variables using Stata. Second edition. USA: Stata Press, Texas.

15. Long JS, 1997. Regression models for categorical and limited dependent variables (RMCLDV). Thousand Oaks CA: Sage Press.

16. Maddala GS, 1983. Limited-dependent and qualitative variables in econometrics. Cambridge: Cambridge University Press.

17. NMA (National Meteorological Agency). (2007).Climate change technology needs assessment report of Ethiopia, Addis Ababa, Ethiopia (http://unfccc.int/ttclear/pdf/TNA/Ethiopia/Ethiopian\%200fficial\%20 TNA\%20Document.pdf).

18. Nwafor, M, AdenikinjuA. andOgujiuba, K. 2007. The impact oftrade liberalization on poverty in Nigeria: dynamic simulationsin a CGE Model. RePEc: lvl: mpiacr: 2007-16. Retrieved on19th November, 2010 from File URL: http://portal.pep-net.org/documents/download/id/8341

19. Reilly, J. M., andFuglie, K. O. (1998). Future yield growth in field crops: what evidence exists? Soil and Tillage Research, 47, 275-290.

20. Rosenberg, N. J. (1992). Adaptation of agriculture to climate change.Climatic Change, 21, 385-405.

21. United Nations Development Programme (UNDP) (2007) Adaptation LearningMechanism: learning through sharing experience. www.adaptationlearning.net

22. USDA (1990).The second appraisal.Washington, DC: United States Department of Agriculture (Miscellaneous Publication No 1482).

23. Ziervogel G., Nyong, A. Osman, B. Conde, C. Cortes, S.andDowing T.(2006). Climate variability and change: implications for household food security. Assessments of Impacts and Adaptations to Climate Change (AIACC) Working Paper No. 20, January 2006. The AIACC Project Office, International START Secretariat, Washington DC, USA.

Citation: Regasa Dibaba, Afework Hagos, Adam Bekele. "Effect of Climate Change on Agricultural Technologies and Determinants of Adaptation Strategies by Small-holder Farmers in Benishangul-Gumuz Regional State of Ethiopia" American Research Journal of Business and Management. 2019; 5(1): 1-17.

Copyright (c) 2019 Regasa Dibaba, Afework Hagos, Adam Bekele. This is an open access article distributed under the Creative Commons Attribution License, which permits unrestricted use, distribution, and reproduction in any medium, provided the original work is properly cited. 